\title{
Social work and the media: A collaborative challenge
}

\section{Deb Stanfield and Liz Beddoe}

Deb Stanfield, PGDipSW, BSW, GDipSup, Academic Staff Member, Centre for Health and Social Practice, Wintec. Liz Beddoe, MA (Social Work), PhD, School of Counselling, Human Services and Social Work, The University of Auckland.

\section{Abstract}

The news media play a substantial role in providing the public with information about social workers, the people they serve and the public perception of issues affecting vulnerable people. This information provides a platform for public discussion and performs a key role in making public opinion about what social workers do and how well they do it. Negative and inaccurate news reporting undermines public confidence in service provision, profoundly challenges the professionalism of social workers, thereby increasing risk to the vulnerable. Resolving this conflict is challenging; social workers and journalists each have motivations, accountabilities and structural issues that lead to the inaccurate media portrayal of social work-related stories. This article focuses on the potential of interprofessional education to better manage these barriers, producing socially responsive journalists, media savvy social workers and a collaborative approach towards social justice and democracy. It offers a sampling of interprofessional education projects between schools of social work and journalism, and makes a case for further study in New Zealand.

\section{Introduction}

Concern has been expressed for several decades about how the social work profession is portrayed in the media (Aldridge 1990; Ayre 2001; Franklin \& Parton 1991; LeCroy \& Stinson 2004; Chenot 2011). This topic has understandable, unavoidable interest for social workers, given both the dominant place of the media in daily life and a natural interest in what others may think of the profession's achievements. It is acceptable for there to be some degree of collective discontent should social workers feel unrecognised for what they consider to be the 'honourable intent' of the profession. More importantly, however, is professional concern for vulnerable and misrepresented members of society.

It is the experience of social work practitioners in the field of statutory child protection, for example, that media stories about child protection (social work) services are predominantly negative, are based on limited or biased information and have unintended consequences for vulnerable children in need of state support (Goddard \& Liddell 1995; Chenot 2011). In New Zealand and internationally, negative news stories undermine public confidence in our collective ability to protect vulnerable people, reducing trust in social service and putting the public at greater risk, yet may rarely lead to positive policy change. Chenot (2011), for example describes a cycle beginning with intense media interest in a child death, followed by a criminal investigation, political claims-making focused on accountability, calls for 
punishment and the implementation of minor policy and practice changes. Chenot argues that these cases then slip into the background and rarely create lasting reform; rather there is a, '...lull in public scrutiny of the agency and the preparatory phase that leads to yet another grievous case, which triggers a spike and the cycle continues' (2011, p.169). These stories profoundly impact the profession of social work by eroding the professionalism of social workers, contributing to high stress levels and low retention rates, and affecting the quality of service provision - again increasing risk to the vulnerable.

It is important to recognise the essential democratic role media plays in challenging the quality of service provision and highlighting the injustice frequently served on a vulnerable public by the state services designed to protect them. The media acts as a necessary watchdog, highlighting social issues and critically analysing how society responds. Social workers remain uncertain, however, about whether this tendency to focus on inadequacies leads to improved service, or whether it has the opposite effect - with potentially tragic consequences (Galilee 2006; Chenot 2011). The social work profession has an ethical and professional obligation to manage this dilemma, a task made more complex by the acknowledged reality of the media world, where output is regulated by time, money, competition and politics.

Significant social work energy has been invested in the pursuit of solutions to this dilemma; some ideas include increasing social work expertise in media-related skills and improving relationships between the professions (Lytollis 1996; Brawley 1997). Very little has changed in the intervening years, however, and it is proposed in this article that inspiration can also be found within the principles of interprofessional education and collaborative practice that it is possible for new ideas and possibilities to emerge if journalists and social workers learn from (and with) each other and work together towards shared goals.

This article will first take a brief look at how social work has so far analysed its relationship with the media. It will then offer a selection of projects that feature joint educational opportunities for social workers and journalists, and will conclude with an analysis of these projects based on concepts of interprofessional education and collaborative practice.

\section{Background}

Intensive media reporting of social work-related stories, primarily those of child protection services, began in earnest in the United Kingdom in the early 1970s during an inquiry into the death of a child and the social worker's role in her care (Franklin \& Parton 1991) and much of the critical commentary on reporting has arisen in the UK. Subsequent child abuse inquiries fuelled exponential media interest, leading to an unprecedented 'climate of fear, mistrust and blame' in the social service sector (Ayre 2001). In what has come to be known as, 'the age of the inquiry' (Stanley \& Manthorpe 2004) it has been widely acknowledged that fear of media exposure can drive defensive practice and increase practitioner anxiety.

Continued 'media bashing' of social workers prompted a number of high profile and far reaching reports in the UK. Important amongst these is a literature review that expressly addresses how social work and social workers are represented in the media, offering a comprehensive review of the history of the media reporting in the UK and an acknowledgement of the continuing problem (Galilee 2006). Further to this, an influential ministerial report (Lord Laming 2009) strongly recommends strategies aimed at overcoming media misunder- 
standings as essential to securing the safety of children in the UK, and a subsequent briefing paper aimed at reviewing the extent to which media coverage of child deaths influences policy confirmed a similar need (Elsley 2010). An extensive review of child protection services in the UK (Munro 2011), pays significant attention to the place of media in the public's poor perception of social workers and urges a need for solutions to be found. The discussion is very much alive right to the present. Warner's recent analysis of media coverage of the Peter Connelly case in the UK led her to argue that, '...politicians, in conjunction with the press, actively mobilised public anger towards social work' due to a 'shared mutual interest in the co-authorship of 'bad' stories about social work' (Warner 2013: 1).

\section{New Zealand}

The experience of the New Zealand social work community largely parallels that of the UK, although there is much less visible scapegoating of individuals. Judge Brown (2000), in his ministerial review of New Zealand's statutory child protection service, Child Youth and Family, reported that, '... as the coalface presence of the organisation, social workers tend to take the brunt of criticism directed at it. 'Many staff leaving Child Youth and Family attribute their decision, in part, to the cumulative, caustic effects of negative media portrayal and poor public perception' (p. 51). The need to address this problem with positive strategies was noted by Lytollis (1996) and the significant problem of media framing of child abuse and Maori families was highlighted by Blank (1999).

A report provided by the New Zealand Children's Commissioner (2003) reviewed the circumstances of specific child abuse deaths and is similarly noted for its criticism of media reporting. The report found that, '...news media violated these children's rights to privacy, respect and dignity' (p. 38). Van Heugten (2011) discusses the stress experienced by social workers in Aotearoa New Zealand, making particular reference to the poor image of social workers in this country, and the excessive criticism directed at the profession both politically and publicly (p.35). Stress experienced by social workers is often cited as being in part a result of the negative press and poor public image, and contributing significantly to poor staff retention rates (Cooper 2005; Dill 2007; Taylor, Beckett, \& McKeigue 2008; Tham 2007).

Important thinking on this issue from a New Zealand perspective is also contributed by Keenan (2000), who reviews the reporting by the New Zealand media on the deaths of two abused Maori children. He refers to the, '...frenzy of media interest in child abuse cases sparked by tragic events overseas' (p. 7), acknowledging the publicity of a recent child death in the UK that was well covered in New Zealand at the time. Keenan highlights two key points; one is the significant impact that events overseas has on the New Zealand social work environment, and the other is the New Zealand media misrepresentation of child abuse as a cultural (Maori) issue. It is well established in the literature that stereotypes and racist perceptions of Maori are reinforced by the media in New Zealand (Spoonley \& Hirsh 1990) and a recent analysis of child abuse reporting in this country confirms this (Merchant 2010).

\section{Solutions}

Explanations have been sought for the unique tensions present between the two professions, both from journalistic and social work perspectives. This analysis began substantially in the early 90s, when the social work profession was criticised by journalists as lacking public relations skills, not having a good 'nose for a story' or being shrouded in 'curtains of confidentiality' (Fry 1991: 65). There was also discussion about the nature of 
social work, its historical and theoretical base, and its poor reputation as contributing factors (Aldridge 1990; Franklin \& Parton 1991). There was an offer of explanation from the news media as to the kinds of stories sought and what dictated the competition for news stories on any given day (Fry 1991). It is clear that little has changed over the last two decades within either profession - the practice of reporting continues to lead to a disparity between social reality and what is represented in the media, and social work still struggles to respond effectively (Ayre 2001; Breen 2005; LaLiberte, Larson, \& Johnston 2011; Thomlison \& Blome 2012).

In response, the literature generally describes the profession of social work as needing to develop further skills in relating to the media and to develop as a profession that has a strong and distinct voice. Suggestions include the development of media liaison positions, media education for social workers and the generation of pools of expertise for media consumption (Franklin \& Parton 1991; Fry 1991; Galilee 2006; Munro 2011). There is also recognition of the need for education of journalists on child protection matters and on the role of the social worker (Breen 2005; Gaber 2011; Ryan, Carragee, \& Schwerner 1998; Seow Ting 2004; Stone, Ekman, English, \& Fujimori 2008; Tobin 2004).

In summary, recommendations emerging from the social work profession primarily promote strategies that focus on the relationship between social worker and the media, either by, ' ...further education for both social workers and journalists, or by strengthening the professionalism of social workers so they are less vulnerable to abuse from the media'. Although the literature is placed predominantly in the UK and the US, a preliminary search reveals a similar experience in Australia (Mendes 2001; Saunders \& Goddard 2002) and in Canada (Harding 2009, 2010; Tonmyr \& Jack 2010).

\section{The education of social workers and journalists}

There are a number of tertiary education projects that focus on the interface between social work and the media; in all cases the rationale given for such projects comes from two places. The first refers to the social advocacy role of social work - the responsibility the profession has to make use of media, and to develop media-related skills. The second and more recent rationale arises from the established media misrepresentation of social work and the risk this poses to vulnerable populations. The corresponding suggestion is that for media reporting to more successfully promote social change, the professions must learn and work together. This call for collaboration is very much a feature of the social and health care fields, and has found its way into the relationship between social work and journalism education.

\section{Social workers becoming media-wise}

It has long been recognised that social workers benefit from having the skills necessary to work with the media, both to enact their role in 'class advocacy' and to shape policy (Tower 2000). There is emphasis on how the media can and should be harnessed for social progress purposes and on how social work pioneers used their relationships with the media as key ways of bringing about social change (Boehm 2004; Briar-Lawson, Martinson, Briar-Bonpane, \& Zox 2011). There is a suggestion that media professionals should be seen by social workers as primary allies given their intimate knowledge of communities and access to the tools of mass communication (Brawley 1997). 
LaLiberte, et al. (2011) strengthen the argument that social workers should be provided with instruction in media-related issues and make a clear case that social workers should take more responsibility for how they are perceived by the public:

Unless there is an understanding that child welfare professionals have a role in questioning, collaborating with, and engaging the media, there is little ground to criticise the media. Social work educators do a good job teaching students about establishing relationships and educating the people with whom they will work and to whom they will provide services: now educators need to teach students to use those skills with the media and the public. Public education works if the public is given messages that there are effective ways to help families and children. Until we are part of the solution of improving media coverage of child welfare issues, we will continue to suffer as part of the problem. Our students deserve better (p. 210).

Social work educators are further criticised for side-lining the social work role in community development, and for focusing primarily on personal and psychodynamic approaches to practice. A further case is thus made for the development of media-related skills and social work expertise in the use of technology - cameras, radio, print and television as media tools. It is suggested that social work knowledge of the media production process helps to develop respect for the limitations and possibilities of the use of media and refocuses social workers on their role in the community (Boehm 2004). There is a strong imperative for social workers to be increasingly media aware, so that the profession remains relevant and social service programmes are supported (Zugazaga, Surette, Mendez, \& Otto 2006).

\section{Social workers and journalists learning together}

This article has so far focused on the professional and social benefits of improved media knowledge for social workers, and on how social work education has met the challenge in this regard. In addition to this, however, there are examples of how social workers and journalists have been brought together in their learning, suggesting a reciprocal benefit for both professions. It introduces the idea of 'true' interprofessional collaboration, not dissimilar to what is currently evident in the fields of health and social care.

Literature about interprofessional education suggests that should interdisciplinary relationships and learning opportunities exist at the learning phases of professions, new skills and alliances can be formed at early stages of professional development (Barr 2012; Bronstein, Mizrahi, Korazim-Ko"rösy, \& McPhee 2010; McLaughlin 2012; Smith \& Anderson 2008). A small number of recent university projects have embraced this collaborative spirit, inviting social work and journalism students into a range of innovative media productions (Briar-Lawson et al. 2011; Gelman \& Tosone 2010; Stone et al. 2008; Zox n.d.; Zugazaga et al. 2006).

Students have been supported to develop a magazine, for example, that addressed current local social issues, and enabled both professions to identify role tensions, to strengthen professional identities and to collaborate on social justice issues (Stone et al. 2008). Another project offered social work and journalism students an opportunity to learn about using visual technologies together by participating in a joint production of a powerful local documentary highlighting key social issues (Gelman \& Tosone 2010). A university radio show is another example of how social work and media educators have collaborated to provide a community service that allows for skills development, joint learning and the expression of the 
common passion of both professions to represent the 'underdog' (Briar-Lawson et al. 2011; Zox n.d.). A final example is that of a teaching programme offering interdisciplinary learning about social change, social welfare and public policy ('Fostering Media Connections' 2013).

\section{Good idea - but does it work?}

There is a general, common-sense agreement that increased collaboration will benefit social workers and journalists in their joint pursuits, and each of these projects makes varying degrees of reference to concepts of collaboration. However, it is acknowledged that to date few clear collaborative structures or pedagogical strategies have been put forward to support this. The last part of this article will look briefly at what experience has to offer in this way - does collaborative practice work? What have we learned so far in this area of practice that can contribute to social workers and journalists in their mission to work with each other?

\section{What does interprofessional collaboration mean?}

The World Health Organisation (2010) defines interprofessional education as when '... students from two or more professions learn about, from, and with each other to enable effective collaboration and improve health outcomes' (p. 7). Bronstein (2003) offers a model of interdisciplinary collaboration for social workers, defining it as, ' ... an effective interpersonal process that facilitates the achievement of goals that cannot be reached when individual professionals act on their own' (p. 299). These definitions sit amongst a range of thinking across disciplines that have come about in response to an understanding that poor health and safety outcomes are linked to a dangerous absence of collaboration between professionals, particularly when vulnerable children and adults are concerned.

Unsafe child protection practice, for example, and unresponsive 'siloed' health services have led to ethical, policy and practice directives in European, North American and Australasian countries (Reeves et al. 2008). It is acknowledged that social work as a profession embraces this mode of practice as an intrinsic principle (International Federation of Social Workers 2012).

There is general agreement in the literature about the qualities of successful collaboration. These include the need for professionals to be interdependent and to have clarity about the benefits of working together. There must be a real possibility that new practice, policies or programmes will come from collaboration, and that there is flexibility and openness to the inevitability of blurred roles. There is reference to the reality of hierarchy or the dynamic of power within the collaboration, and the willingness of participants to negotiate this. Collaborators must collectively 'own' practice goals and attend to competing interests, and the group must reflect critically on the process of the work done together (Berg-Weger \& Schneider 1998; Bronstein et al. 2010; Smith \& Anderson 2008). Most importantly, there is agreement that the key indicator of good interprofessional collaboration lies in the extent to which it meets the client's needs (McLaughlin 2012).

There is also clear acknowledgement of the limitations of collaborative practice, including some concern that it has progressed without empirical evidence of its effectiveness (McLaughlin 2012; Reeves et al. 2008; Smith \& Anderson 2008). Potential dangers in interprofessional practice include collusion between the professionals, role confusion, blurring of boundaries and role and professional jealousy (McLaughlin 2012). Smith and Anderson (2008) caution that, ' ...an over-concentration on establishing good interpersonal and in- 
terprofessional relationships may obscure the underlying objective of working to improve the collective ability to provide appropriate and effective services' (p. 764). There are also potential problems with power imbalance when a number of professionals are working with a vulnerable population. Hall (2005) also notes the significance of different cultures and histories of professions and how these have evolved as each profession has established its territory. Each profession has fought to define its identity, sphere of influence and values. The socialisation process which occurs during preparatory phases, '...serves to solidify the professional's unique world view' (Hall 2005: 190) and may contribute to misunderstanding and conflict between professions.

\section{Collaboration between social work and journalism - is it worth pursuing?}

The last part of this article considers what social work and journalism educators learn from the 'good' and the 'ugly' of collaborative practice. Can lessons be brought forward from what social workers have already learned and be applied to this tentative collaborative relationship?

\section{What is our common goal?}

The first question to ask is to what extent there is a common goal between social workers and journalists. Social workers have a clear role as agents of social change; the public is their 'client'. Journalists have a strong connection with democracy and a primary purpose of providing the public with information it needs to be self-governing and free (Kovach \& Rosenstiel 2001: 12). Both professions have a social conscience that focuses on a quest for truth, justice and liberty. It is not difficult to find a common purpose, ideal as it may seem - social workers and journalists both frequently enter their respective professions with the altruistic intention of protecting the 'underdog' (Briar-Lawson et al. 2011). There may be differences in how each profession strives to achieve this goal, however, it is difficult to argue this broad shared purpose.

\section{What can we offer each other?}

It has been acknowledged that social workers benefit from and should take advantage of the expertise of media professionals. As already stated, there are opportunities to promote public awareness of social issues, to work alongside the media to encourage more in-depth reporting of social issues and social work, to embrace the technology always thought to be the domain of journalists, and to use public media outlets as a way to bring about social change. Journalists draw on theories of communication and have valuable practice knowledge of community and societal dynamics that social workers can draw on.

There has been little written from a media perspective, however, about what social workers can offer journalists. This is a key area for further research, however, a good beginning and clear inspiration can be found in how social work already distinguishes itself as a profession and hence what it offers in any collaborative relationship. Smith and Anderson (2008) offer a description of the key role that social work holds in any interprofessional collaboration:

This must be grasped as an opportunity to promote key values such as 'empowerment' and user-centred practice, and to establish clearly the legitimacy of this way of working. These principles, the associated knowledge of the 'social' nature of people's problems, and the key skills of networking and holistic problem-solving are distinctive (if not exclusive) to social work. It is thus the case that the profession has a major contribution to make in shaping interventions so that they reflect these elements of good practice (p. 774). 
Following from this, it is almost too easy (for a social worker) to come up with a number of social work skills and perspectives with potential of adding to or supporting the competence with which journalists engage with the public. Social workers have highly refined interviewing and interpersonal engagement skills, including specialist work in the midst of crisis and grief, they have skills in networking, community engagement, working with and empowering vulnerable people, including minorities and victims. Social workers have the theoretical knowledge to critically analyse complex social situations and policies that affect the very people whose stories journalists are interested in telling.

\section{Identity and integrity}

Successful collaboration relies on the ability of professionals to maintain identity and integrity and to manage the misconceptions each profession has of the other - a problem that is frequently cited as a key contributor to how social workers are portrayed in the media (Franklin \& Parton 1991). Good interprofessional collaboration provides a place where boundaries are drawn and, in the case of social work and journalism, can be where negotiation can occur about the role each profession can take in media-related activities. This has a great deal of exciting potential for research, some of which has started, as already described in the discussion of joint projects between social work and journalism students.

Concepts of community journalism, advocacy journalism, media-assisted prevention and social marketing, for example, all occupy places on a continuum of journalistic practices in the context of social responsibility. There are significant challenges in this field regarding the redefinition of journalism based on changes in technology (Claussen 2010; Strong 2012) and in reporting of diversity (Biswas \& Izard 2010), and it is crucial to gain an understanding of this changing landscape in order to develop a useful picture of how social workers and journalists intersect in their work. It has already been put forward that social work as a profession should be more than usually engaged in media activities given its principles of social justice and commitment to social change/advocacy - activities which require an expertise in networking, communication skills and 'media consciousness' (Briar Lawson, et al. 2011; Gelman \& Tosone 2010; LaLiberte, et al. 2011; Tower 2000).

Given the rise of 'citizen journalism', whereby those other than traditional journalists contribute to the dissemination of news and opinion, an additional path has been cleared for social workers to use social media to effectively engage in this aspect of their professional role. Social workers, particularly in the UK, are engaging in social media activities for professional development and support, and to highlight and learn about social issues pertinent to their field of practice (Kimball \& Kim 2013). It is suggested that New Zealand social workers follow suit (Ballantyne 2013) and further research into how social workers are using social media is recommended.

\section{Where might it not work? Being explicit about limitations...}

There is a perceived danger in this discussion of offering a superficial analysis of the complexity of the political, economic and social landscape impacting on both social workers and journalists. Both professions face significant barriers to achieving their professional and ethical goals. It is suggested that principles of collaborative practice are at the very least useful in assisting with the mandate for this discussion, but it is clear that much more analysis is necessary at various levels to fully comprehend and manage the issue. It is also important that this analysis be done at a local level so as to embrace the unique qualities of Aotearoa New Zealand so often not represented in the literature. Caution can at least 
be offered, however, regarding each profession's tendency to sidestep the economic and political realities impacting on the other, and a suggestion can be made that establishing a good collaborative stance is a way of avoiding this behaviour.

Good collaborative practice 'doesn't just happen'; it relies on successful management of interpersonal dynamics, and honesty about the reality of hierarchy and power. Key tensions inevitably exist in all professional collaborations and frequently serve to undermine the achievement of joint goals. The use of critical reflection, as advocated for by principles of collaborative practice, offers a way of successfully managing these dynamics. This has limited impact, however, if structural and professional support is not offered. This is a tall order, however, social workers with the skills and knowledge of media practice and with good collaborative relationships with the media are well situated to provide key leadership within professional organisations and workplaces.

It is critical to return to McLaughlin's wisdom about the danger of assuming that working from a collaborative, interprofessional perspective is inherently good:

I would like to suggest that it is as bad to practise mono-professionally when an interprofessional approach is required, as to practise in an interprofessional way when a mono-professional approach is required (McLaughlin 2012: 7).

This emphasises the importance of maintaining a focus on the limitations of working together, and not accepting wholeheartedly the apparent common sense wisdom that it is always a good thing.

\section{Conclusion}

This article set out to consider the tensions that exist between social work and the media and the risk this poses to vulnerable people and to the pursuit of social justice and human rights. Examples were provided from the literature of recent interprofessional teaching programmes at tertiary education levels that showcase collaborative student ventures, including film, radio, news and websites/blogs. These projects are designed both to assist social workers to acquire media-related skills and knowledge, and to involve social work and journalism students in joint learning projects. Models of interprofessional collaboration were considered in the context of these endeavours and a case made for four key areas of collaboration: mass communication skills, social advocacy, social research and analysis, and interpersonal or micro-communication skills. Limitations of collaborative practice as applied to these professions were identified, including the significant reality of complex structural barriers between and within the professions. And finally, a case was made for future research in New Zealand, particularly into the areas of interprofessional education between social work and journalism, the potential of social media to the profession, and the unique structural characteristics of each profession that contribute to reporting of social work issues in Aotearoa New Zealand.

\section{References}

Aldridge, M. (1990). Social work and the news media: A hopeless case? British Journal of Social Work 20(6): 611-625. Ayre, P. (2001). Child protection and the media: Lessons from the last three decades. British Journal of Social Work 31(6): 887-901. doi: 10.1093/bjsw/31.6.887. 
Barr, H. (2012). Toward a theoretical framework for interprofessional education. Journal of Interprofessional Care, Early Online 1-6. doi: 10.3109/13561820.2012.698328.

Ballantyne, N. (2013, December 3). Reflections on social workers E social media in Aotearoa: Part 1 [Web log post]. Retrieved from http:/ / socialworkresearchnz.wordpress.com/2013/12/03/reflections-on-social-workerssocial-media-in-aotearoa-part-1/.

Berg-Weger, M., \& Schneider, F.D. (1998). Interdisciplinary collaboration in social work education. Journal of Social Work Education 97-107.

Biswas, M., \& Izard, R. (2010). Assessment of the status of diversity education in journalism and mass communication programs. Journalism \& Mass Communication Educator 64(4): 378-394.

Blank, A. (1999). Maori, the media, racism and neglect. Social Work Now 14: 41-45.

Boehm, A. (2004). Integrating media and community practice: a case of television report production. Social Work Education 23(4): 417-434.

Brawley, E. (1997). Teaching social work students to use advocacy skills through the mass media. Journal of Social Work Education 33(3): 445-460.

Breen, M.J. (2005). How media content assists and neglects child safety. Canada's Children (Fall): 5-8.

Briar-Lawson, K., Martinson, K., Briar-Bonpane, J., \& Zox, K. (2011). Child welfare, the media, and capacity building. Journal of Public Child Welfare 5(2/3): 185-199. doi: 10.1080/15548732.2011.566754.

Bronstein, L.R. (2003). A model for interdisciplinary collaboration. Social Work 48(3): 297-306.

Bronstein, L.R., Mizrahi, T., Korazim-Ko"rösy, Y., \& McPhee, D. (2010). Interdisciplinary collaboration in social work education in the USA, Israel and Canada: Deans' and directors' perspectives. International Social Work 53(4): 457-473. doi: $10.1177 / 0020872809358399$.

Brown, M. (2000). Care and protection is about adult behaviour. Report to the Minister of Social Services and Employment: Wellington.

Chenot, D. (2011). The vicious cycle: Recurrent interactions among the media, politicians, the public, and child welfare services organizations. Journal of Public Child Welfare 5(2-3): 167-184. 10.1080/15548732.2011.566752.

Claussen, D. (2010). JMC professors can seize the moment, or at least not embarrass ourselves. Journalism $\mathcal{E}$ Mass Communication Educator 65(2): 117-120.

Cooper, L. (2005). Implications of media scrutiny for a child protection agency. Journal of Sociology E Social Welfare 32(3): 107-121.

Dill, K. (2007). Impact of stressors on front-line child welfare supervisors. Clinical Supervisor 26(1/2): 177. doi: $10.1300 /$ J001v26n01.12.

Elsley, S. (2010). Media coverage of child deaths in the UK: The impact of baby P: A case for influence? The University of Edinburgh/NSPCC.

Fostering Media Connections. (2013). Retrieved 18 August 2013, from http:/ / fosteringmediaconnections.org.

Franklin, B., \& Parton, N. (1991). Social work, the media and public relations. London: Routledge.

Fry, A. (1991). Reporting social work: A view from the newsroom. In B. Franklin \& N. Parton (Eds.). Social work, the media and public relations. London: Routledge.

Gaber, I. (2011). Child abuse: The media must listen. British Journalism Review 22(3): 57-63.

Galilee, J. (2006). Literature review on media representations of social work and social workers. Edinburgh: Scottish Executive.

Gelman, C.R., \& Tosone, C. (2010). Teaching social workers to harness technology and inter-disciplinary collaboration for community service. British Journal of Social Work 40(1): 226-238.

Goddard, C., \& Liddell, M. (1995). Child abuse fatalities and the media: Lessons from a case study. Child Abuse Review 4(5): 356-364. 10.1002/ car.226.

Hall, P. (2005). Interprofessional teamwork: Professional cultures as barriers. Journal of Interprofessional Care 19(s1): 188-196. doi:10.1080/13561820500081745.

Harding, R. (2009). News reporting on aboriginal child welfare: Discourses of white guilt, reverse racism and failed policy. Canadian Social Work Review 26(1): 25-41.

Harding, R. (2010). The demonization of Aboriginal child welfare authorities in the news. Canadian Journal of Communication 35(1): 85-108.

International Federation of Social Workers. (2012). Retrieved from http:/ / ifsw.org/resources/definition-of-social-work/.

Keenan, D. (2000). Hine's Once Were Warriors hell: The reporting and racialising of child abuse. Social Work Review 12(4): 5-8.

Kimball, E., \& Kim, J. (2013). Virtual boundaries: Ethical considerations for use of social media in social work. Social Work 58(2): 185-188.

Kovach, B. \& Rosenstiel, T. (2001). The elements of journalism: What newspeople should know and the public should expect. New York: Three Rivers Press.

LaLiberte, T., Larson, A., \& Johnston, N. (2011). Child welfare and media: Teaching students to be advocates. Journal of Public Child Welfare 5(2/3): 200-212. doi: 10.1080/15548732.2011.566757.

LeCroy, C., \& Stinson, E. (2004). The public's perception of social work: Is it what we think it is? Social Work 49(2): 164-175.

Lord Laming. (2009). The protection of children in england: A progress report. London: The Stationery Office.

Lytollis, S. (1996). Making the best of the media spotlight. Social Work Now (5): 15-20. 
McLaughlin, H. (2012). Motherhood, apple pie and interprofessional working. Social Work Education: The International Journal. http: / / dx.doi.org/10.1080/02615479.2012.709841.

Mendes, P. (2001). Blaming the messenger: The media, social workers and child abuse. Australian Social Work 54(2): 27-36.

Merchant, R. (2010). Who are abusing our children? An exploratory study on reflections on child abuse by media commentators. (MSW), Massey University, Palmerston North. Retrieved from http://hdl.handle.net/10179/1612.

Munro, E. (2011). The Munro review of child protection: Final report; a child-centred system. London: The Stationery Office.

Office of the Commissioner for Children. (2003). Report into the investigation into the deaths of Saliel Jalessa Aplin and Olympia Marisa Aplin. Wellington: Office of the Commissioner for Children (NZ Govt).

Reeves, S., Zwarenstein, M., Goldman, J., Barr, H., Freeth, D., Hammick, M., \& Koppel, I. (2008). Interprofessional education: Effects on professional practice and health care outcomes. Cochrane database of systematic reviews, 1 .

Ryan, C., Carragee, K., \& Schwerner, C. (1998). Media, movements, and the quest for social justice. Journal of Applied Communication Research 26(2): 165-181.

Saunders, B.J., \& Goddard, C. (2002). The role of mass media in facilitating community education and child abuse prevention strategies. Issues paper 16, National Child Protection Clearinghouse. Melbourne: Australian Institute of Family Studies.

Seow Ting, L. (2004). Lying to tell the truth: Journalists and the social context of deception. Mass Communication $\mathcal{E}$ Society 7(1): 97-120.

Smith, R., \& Anderson, L. (2008). Interprofessional learning: Aspiration or achievement? Social Work Education 27(7): 759-776.

Spoonley, P., \& Hirsh, W. (Eds.). (1990). Between the lines: Racism and the New Zealand media. Auckland: Heinemann Reed.

Stanley, N., \& Manthorpe, J. (Eds.). (2004). The age of the inquiry: Learning and blaming in health and social care. London: Routledge.

Stone, S., Ekman, E., English, D., \& Fujimori, S. (2008). Collaboration among social work and journalism students and faculty - an instructional model. Journal of Social Work Education 44(1): 163-172.

Strong, C. (2012). Teaching converged media to Arab students: University/external partnerships in social media campaigns. Middle East Media Educator 1(2): 87-99.

Taylor, H., Beckett, C., \& McKeigue, B. (2008). Judgements of Solomon: Anxieties and defences of social workers involved in care proceedings. Child E Family Social Work 13(1): 23-31.

Tham, P. (2007). Why are they leaving? Factors affecting intention to leave among social workers in child welfare. British Journal of Social Work 37(7): 1225-1246. doi: 10.1093/bjsw / bcl054.

Thomlison, B., \& Blome, W. (2012). Hold the presses: A commentary on the effects of media coverage of fatalities on the child welfare system. Journal of Public Child Welfare 6(3): 243-254.

Tobin, J. (2004). Partners worth courting: The relationship between the media and the Convention on the Rights of the Child. International Journal of Children's Rights 12(2): 139-167. doi: 10.1163/1571818041904326.

Tonmyr, L., \& Jack, S. (2010). Media analysis of early dissemination of Canadian child maltreatment surveillance data. Child Welfare 89(1): 81-101.

Tower, K. (2000). In our own image: Shaping attitudes about social work through television production. Journal of Social Work Education 36(3): 575-586.

Van Heugten, K. (2011). Social work under pressure: How to overcome stress, fatigue and burnout in the workplace. London: Jessica Kingsley Publishers.

Warner, J. (2013). 'Heads must roll'? Emotional politics, the press and the death of Baby P. British Journal of Social Work: doi:10.1093/bjsw/bct039.

World Health Organisation. (2010). Framework for action on interprofessional education E collaborative practice. Retrieved 26 August 2013 from http: / / www.who.int/hrh/resources/framework_action/en/.

Zox, K. (n.d.). Your social worker with a microphone. Retrieved 13 October 2012, from http: / / www.kathrynzox.com/ index.asp.

Zugazaga, C.B., Surette, R.B., Mendez, M., \& Otto, C.W. (2006). Social worker perceptions of the portrayal of the profession in the news and entertainment media: An exploratory study. Journal of Social Work Education 42(3): 621-636. 